\title{
Self-esteem and health-related quality of life in ostomized patients
}

\author{
Autoestima e qualidade de vida relacionada à saúde de estomizados \\ Autoestima y calidad de vida relacionada a la salud de ostomizados
}

\section{Emmanuelle da Cunha Ferreira', Maria Helena Barbosa", Helena Megumi Sonobe" ${ }^{\text {III }}$ Elizabeth Barichello"}

' Universidade Federal do Triângulo Mineiro, Postgraduate Program in Health Care. Uberaba, Minas Gerais, Brazil.

"Universidade Federal do Triângulo Mineiro, Hospital Care Nursing Department, Postgraduate Program in Health Care. Uberaba, Minas Gerais, Brazil.

I' Universidade de São Paulo, Ribeirão Preto College of Nursing. Ribeirão Preto, São Paulo, Brazil.

\begin{abstract}
How to cite this article:
Ferreira EC, Barbosa MH, Sonobe HM, Barichello E. Self-esteem and health-related quality of life in ostomized patients. Rev Bras Enferm [Internet]. 2017;70(2):271-8. DOI: http://dx.doi.org/ 10.1590/0034-7167-2016-0161
\end{abstract}

\section{Submission: 07-17-2016 Approval: 09-28-2016}

\begin{abstract}
Objective: to assess self-esteem (SE) and health-related quality of life (HRQoL) in ostomized patients due to colorectal cancer. Method: cross sectional research with a quantitative approach. Three instruments were used for data collection: one instrument containing sociodemographic and clinical data, Rosenberg's Self-Esteem Scale, and the European Organization for Research and Treatment of Cancer Quality of Life Questionnaire. Results: SE and HRQoL were considered satisfactory. Significant statistical difference was found in the social function domain and marital status, ostomy duration, location, and time; global health scale and ostomy type; cognitive function and pain in the ostomy site. There was a correlation between self-esteem and all the functional scales and the global health scale. Conclusion: knowing SE and HRQoL levels, in addition to the variables that influence them, supports ostomized patients' care planning, rehabilitation, and social autonomy.
\end{abstract}

Descriptors: Ostomy; Colorectal Neoplasms; Self Concept; Quality of Life; Oncology Nursing.

\section{RESUMO}

Objetivo: avaliar a autoestima (AE) e a qualidade de vida relacionada à saúde (QVRS) de pacientes estomizados por câncer colorretal. Método: estudo transversal com abordagem quantitativa. Utilizaram-se três instrumentos para a coleta de dados: um contendo dados sociodemográficos e clínicos, a Escala de Autoestima de Rosenberg e o European Organization for Research and Treatment of Cancer Quality of Life Questionnaire. Resultados: a AE e a QVRS foram consideradas satisfatórias. Verificouse diferença estatisticamente significante entre: o domínio função social e situação conjugal, duração, localização e tempo de estomia; a escala global de saúde com o tipo de estomia; a função cognitiva e dor com local da estomia. Houve correlação entre a autoestima e todas as escalas funcionais e a escala global de saúde. Conclusão: conhecer os níveis de AE e QVRS, e como as variáveis que os influenciam subsidiam o planejamento do cuidado, a reabilitação e a autonomia social do estomizado.

Descritores: Estomia; Neoplasias Colorretais; Autoimagem; Qualidade de Vida; Enfermagem Oncológica.

\section{RESUMEN}

Objetivo: evaluar autoestima (AE) y calidad de vida relacionada a la salud (QVRS) de pacientes ostomizados por cáncer colorrectal. Método: estudio transversal con abordaje cuantitativo. Datos obtenidos mediante tres instrumentos: uno incluyendo datos sociodemográficos y clínicos; la Escala de Autoestima de Rosenberg y el European Organization for Research and Treatment of Cancer Quality of Life Questionnaire. Resultados: La AE y la QVRS fueron consideradas satisfactorias. Se verificó diferencia estadísticamente significativa entre: dominio función social y situación conyugal, duración, localización y tiempo de ostomía; escala global de salud con tipo de ostomía; función cognitiva y dolor con lugar de ostomía. Hubo correlación entre autoestima y todas las escalas funcionales y la escala global de salud. Conclusión: conocer los niveles de AE y QVRS y cómo los influyen las variables, ayuda con la planificación del cuidado, la rehabilitación y la autonomía social del ostomizado.

Descriptores: Estomía; Neoplasias Colorrectales; Autoimagen; Calidad de Vida; Enfermería Oncológica. 


\section{INTRODUCTION}

The magnitude of noncommunicable diseases (NCDs) is measured by the ratio of deaths, limitations and handicaps, impact on quality of life, and economic burden shared among the health care system, families and society in general. In Brazil, NCDs are the most critical health problem and account for $72 \%$ of deaths, especially cardiovascular diseases, chronic respiratory illnesses, diabetes, and cancer $^{(1)}$.

By 2030, global estimates are 27 million cancer cases and 13.2 million deaths caused by NCDs. According to the estimates for cancer incidence in Brazil for 2016 (which are also valid for the year of 2017), approximately 596,000 new cases of cancer will be diagnosed. The most common will be nonmelanoma skin cancer, followed by prostate, female breast, colon and rectum, lung, and cervix tumors. These data strengthen the magnitude of this illness worldwide, in addition to its social and economic impact ${ }^{(2)}$.

Colorectal cancer (CRC) is one of the most frequent malignant neoplasms of the gastrointestinal tract $t^{(3-4)}$. The name CRC refers to the type of cancer that affects the colon, rectosigmoid junction, rectum, anus, and anal canal ${ }^{(5)}$. In Brazil, the estimate for 2016 is 16,660 cases in men and 17,620 in women ${ }^{(2)}$.

Surgery is the main treatment for most of the colon and rectum cancers. The surgery type and extension depend on the tumor location and size. In general, the surgery demands wide resection of the intestinal loop and adjacent lymphatic tissue ${ }^{(6)}$.

Colostomies and ileostomies can be both temporary and permanent. Temporary stomas are created to preserve an anastomosis and perform a later reconstruction of the intestinal transit, whereas permanent stomas are usually created in the treatment of cancer when the reconstruction is impossible after the distal segment of the bowel has been removed ${ }^{(7)}$.

The result of surgical treatment depends on patients' psychosocial preparation in the preoperative period, when feelings of anxiety and fear related to the anesthesia, changes in the body image and in life style, concerns with the death risk and with the surgical procedure itself may surface ${ }^{(6)}$.

Despite the enhancement of the techniques used, oncology surgeries to open a stoma have mutilation consequences that cause functional and anatomic losses. Ostomized patients are confronted with a multitude of physical, psychological, spiritual, social, and sexual changes that impact their self-esteem $(\mathrm{SE})$ and health-related quality of life $(\mathrm{HRQOL})^{(8)}$.

Self-esteem is an important issue in terms of colorectal cancer. In addition to the stigma of cancer and its body location, patients' concerns are intensified by some therapeutic possibilities, among which divert the intestinal transit through the creation of a stoma. A social stigma is incorporated by these patients, that is, they feel different in comparison with their family and society as a whole, which may hinder their acceptance and adaptation process ${ }^{(9)}$.

Self-esteem is evidenced in the answers given by individuals to different situations and life events ${ }^{(10)}$. It is the most frequently used construct in terms of the thoughts and feelings individuals have of themselves ${ }^{(11)}$. The creation of a stoma may result in a distorted image and reduced self-esteem, echoing in patients' perception of themselves. People see themselves as lacking attraction. The sudden change in body image creates confusion and negative changes in the way people perceive themselves ${ }^{(12)}$.

The increasing emphasis on HRQoL assessment among individuals who underwent anti-neoplasic treatment derives from factors such as the advances in the detection and treatment of the disease, the need to measure the impact of the therapy, more optimistic social attitudes, increasing number of survivors, and concerns with patients' rights $^{(13)}$.

The HRQoL terminology refers to the value that may be attributed to life or perceived health state resulting from changes that may occur because of damages in the functional state, perceptions and social factors when influenced by diseases, treatment, and health policies ${ }^{(14)}$. Therefore, the evaluation of this construct assumes an instrumental character as it offers healthcare professionals a better understanding of how different practices and therapies influence the results among individuals ${ }^{(15)}$.

In face of this, the objectives of this study were to assess SE and determine the influence of sociodemographic and clinical data on SE, to determine the domains of HRQoL, and to analyze the influence of sociodemographic and clinical data and self-esteem on health-related quality of life.

\section{METHOD}

\section{Ethical aspects}

The development of the current study began after approval by a human research ethics committee. Participants signed a free consent agreement.

\section{Study design, setting, and period}

A cross-sectional study was conducted with 36 ostomized patients at the outpatient specialty clinic of the Triângulo Mineiro Federal University (UFTM), in the city of Uberaba, state of Minas Gerais. Ostomized patients were actively sought in the records of the Multidisciplinary Care Program for Ostomized Patients (PAMPO, as per its acronym in Portuguese), in the period of June and July 2015.

\section{Population or sample; inclusion and exclusion criteria}

This study included ostomized patients diagnosed with colorectal cancer, aged 18 years or older, who had attended at least one appointment at the outpatient clinic. Those whose intestinal ostomy was not related to colorectal cancer, with cognitive disability, or physical handicap to answer the interviews were excluded.

\section{Study protocol}

Three instruments were used to collect data: a questionnaire containing sociodemographic and clinical data, Rosenberg's self-esteem scale (RSS), and the European Organization for Research and Treatment of Cancer Quality of Life Questionnaire Core 30 items (EORTC-QLQ-C30) to assess HRQoL aspects.

A specific instrument was created to obtain clinical and sociodemographic characteristics. This instrument was submitted for content and face validation by three PhD nurses who work on this subject. 
To assess SE, the RSS was applied. The scale comprised 10 questions, with the following answers to chose from: I fully agree, I agree, I disagree, and I fully disagree ${ }^{(16)}$. A score varying from 1 to 4 was applied to each answer. For questions 2, 5, 6, 8, and 9 , the score was applied in decreasing order; for the remaining questions, an increasing order was applied. Thus, the higher the score in the scale, the lowest the participant's self-esteem.

The European Organization for Research and Treatment of Cancer Quality of Life Questionnaire Core 30 items is a HRQoL questionnaire duly validated for our population ${ }^{(17)}$, for specific use among patients with cancer. It comprises 30 questions that make up five functional scales: physical, emotional, cognitive and social functions, and role playing; a global health status scale $(\mathrm{GHS} / \mathrm{QoL})$, three symptom scales to measure fatigue, pain, nausea and vomiting, and six single items to evaluate dyspnea, insomnia, appetite loss, constipation, diarrhea, and financial impact of the treatment and illness. The scores of scales and measures vary from 0 to 100. A high value score represents a high response level. High GHS and functional scale scores represent a healthful functional level, whereas a high score in the symptom and single items scales represents a high level of symptoms ${ }^{(17)}$.

\section{Analysis of results and statistics}

For the data analysis, software SPSS version 20.0 was used, additionally to Cronbach's Alpha internal consistency test to assess the reliability of the instruments. In a bivariate analysis, the self-esteem scores for groups defined by category variables were compared using the t-Test, and the quality of life scores were compared via nonparametric Mann-Whitney's test. The ratio between the self-esteem and quality of life scores and the quantitative variables was produced by using Pearson's correlation.

This study it is part of a research project called Qualidade de vida nos pacientes com câncer (Quality of life of patients with cancer), which was financially sponsored by the Minas Gerais State Agency for Research and Development (FAPEMIG, as per its acronym in Portuguese).

\section{RESULTS}

Of the 36 ostomized patients due to colorectal cancer, 20 $(55.6 \%)$ were male and $16(44.44 \%)$ were female. Their mean age was 63.97 years, varying from 30 to 81 years old. Regarding schooling, the mean number of years of study was 6.94 . Thirteen patients $(36.1 \%$ ) had between one and four years of schooling; seven (19.5\%) had between five and eight years; thirteen (36.1\%) had between nine and eleven years; and three $(8.3 \%)$ had no schooling at all. In terms of marital status, 19 patients $(52.8 \%)$ had a spouse; seven $(19.4 \%)$ were single; six $(16.7 \%)$ were widowed; and four $(11.1 \%)$ were divorced. As far as occupation and religion were concerned, most participants, $24(66.7 \%)$, were retired and 25 (69.4\%) were Roman Catholic, respectively.

In terms of clinical data, the time living with the stoma was divided into three ranges: 14 patients $(38.9 \%)$ had had the stoma for 12 months or less; 12 (33.3\%) had had it for a period between 13 and 60 months; and 10 (27.8\%) had been with a stoma for more than 60 months. Regarding the ostomy type, there was a predominance of colostomies: 33 (91.7\%), located in the left abdominal quadrant and permanent (63.9\%). As far as complications related to the stoma were concerned, 27 $(75 \%)$ patients reported having none and nine $(25.0 \%)$ said they had some. Of these, four participants $(11.1 \%)$ had had hernia, two $(5.6 \%)$ had had prolapse, and one $(2.8 \%)$ had had bleeding, stenosis, and dermatitis. The majority of the ostomized patients said they had not been previously informed about the opening of the stoma $(77.8 \%)$.

When analyzing results referring to $\mathrm{SE}$, the minimum score was 10 and the maximum was 31 . The mean was 18.88 and the median was 20.0. Cronbach's alpha was 0.9 , which points out to high internal consistency and homogeneity of the items.

Rosenberg's self-esteem scale does not have cut-off points; thus, the entire scores were analyzed, considering that the higher the score, the lower the self-esteem. Comparing the SE means and category variables, only the clinical variable stoma location had a significantly statistic difference $(p=0.03)$. Individuals whose ostomy was on the left side had lower means; therefore, their self-esteem was better. Regarding the variables sex, marital status, stoma type, and time of stoma, there were no statistically significant results.

Table 1 shows the calculations of means, standard deviations, and the result of the Cronbach's alpha test for each EORTC QLQ-C30 domain with more than one item. The Global Health Status/QoL reached the mean 77.77. This shows that ostomized patients consider their quality of life satisfactory as their score is close to 100 (maximum score).

Table 1 - Position and variability measures for domains of the European Organization for Research and Treatment of Cancer Quality of Life Questionnaire Core 30 items (EORTC-QLQ-C30) in ostomized patients secondary to colorectal cancer, Uberaba, Minas Gerais, Brazil, 2015

\begin{tabular}{lccc}
\hline Scales and symptoms & Mean & $\begin{array}{c}\text { Standard } \\
\text { deviation }\end{array}$ & $\begin{array}{c}\text { Cronbach's } \\
\text { alpha }\end{array}$ \\
\hline Global Health Status (GHS) & 77.77 & 23.82 & 0.76 \\
Physical function (PF) & 72.40 & 24.02 & 0.73 \\
Role playing (RP) & 60.64 & 36.91 & 0.68 \\
Emotional function (EF) & 62.69 & 31.92 & 0.77 \\
Cognitive function (CF) & 77.28 & 27.69 & 0.43 \\
Social function (SF) & 71.78 & 32.25 & 0.69 \\
Fatigue (FAT) & 19.98 & 28.32 & 0.71 \\
Nausea and vomiting (NAV) & 4.61 & 10.91 & 0.19 \\
Pain (Pain) & 19.44 & 30.93 & 0.74 \\
Dyspnea (DYS) & 7.39 & 24.03 & - \\
Insomnia (INS) & 37.08 & 41.29 & - \\
Appetite loss (APL) & 21.33 & 34.94 & - \\
Constipation (CON) & 10.19 & 25.01 & - \\
Diarrhea (DIA) & 8.31 & 18.48 & - \\
Financial difficulty (FID) & 31.47 & 40.61 & - \\
\hline
\end{tabular}


Table 2 - Mean, standard deviation and statistic significance of Quality of Life Questionnaire Core 30 items (QLC-C30) application with sociodemographic and clinical data, Uberaba, Minas Gerais, Brazil, 2015

\begin{tabular}{|c|c|c|c|c|c|}
\hline Scale & Sociodemographic and clinical data & Variable & Mean & Standard deviation & $p$ value \\
\hline \multirow[t]{2}{*}{ Social function } & \multirow[t]{2}{*}{ Marital status } & With spouse & 57.95 & 36.09 & \multirow{2}{*}{0.01} \\
\hline & & Without spouse & 87.24 & 18.15 & \\
\hline \multirow[t]{2}{*}{ Financial difficulty } & \multirow[t]{2}{*}{ Marital status } & With spouse & 45.58 & 43.37 & \multirow{2}{*}{0.03} \\
\hline & & Without spouse & 15.71 & 31.49 & \\
\hline \multirow[t]{2}{*}{ Global Health Status } & \multirow[t]{2}{*}{ Ostomy type } & Colostomy & 80.04 & 23.19 & \multirow{2}{*}{0.04} \\
\hline & & Ileostomy & 52.78 & 17.36 & \\
\hline \multirow[t]{2}{*}{ Social function } & \multirow[t]{2}{*}{ Time of stoma } & Temporary & 53.85 & 35.98 & \multirow{2}{*}{0.01} \\
\hline & & Permanent & 81.91 & 25.52 & \\
\hline \multirow[t]{2}{*}{ Cognitive function } & \multirow[t]{2}{*}{ Location of stoma } & Right quadrant & 61.46 & 24.98 & \multirow{2}{*}{0.04} \\
\hline & & Left quadrant & 86.22 & 25.45 & \\
\hline \multirow[t]{2}{*}{ Social function } & \multirow[t]{2}{*}{ Location of stoma } & Right quadrant & 53.85 & 33.37 & \multirow{2}{*}{0.01} \\
\hline & & Left quadrant & 81.91 & 27.39 & \\
\hline \multirow[t]{2}{*}{ Pain } & \multirow[t]{2}{*}{ Location of stoma } & Right quadrant & 39.69 & 40.49 & \multirow{2}{*}{0.02} \\
\hline & & Left quadrant & 8.00 & 15.78 & \\
\hline
\end{tabular}

Table 3 - Pearson's correlation between domains of the European Organization for Research and Treatment of cancer Quality of Life Questionnaire Core 30 items (EORTC-QLQ-C30) and the sociodemographic and clinical variables and self-esteem, Uberaba, Minas Gerais, Brazil, 2015

\begin{tabular}{lccccccccc}
\hline & \multicolumn{2}{c}{ Age } & Schooling & $\begin{array}{c}\text { Time of } \\
\text { ostomy }\end{array}$ & $\begin{array}{c}\text { Self-esteem } \\
\text { score }\end{array}$ \\
\cline { 2 - 9 } Scale & $\mathbf{r}^{*}$ & $\mathbf{p}^{* *}$ & $\mathbf{r}^{*}$ & $\mathbf{p}^{* *}$ & $\mathbf{r}^{*}$ & $\mathbf{p}^{* *}$ & $\mathbf{r}^{*}$ & $\mathbf{p}^{* *}$ \\
\hline Global Health Status & 0.35 & 0.03 & -0.10 & 0.53 & 0.19 & 0.24 & -0.64 & $<\mathbf{0 . 0 0 1}$ \\
Physical function & 0.20 & 0.22 & -0.93 & 0.58 & 0.07 & 0.65 & -0.56 & $<\mathbf{0 . 0 0 1}$ \\
Role playing & 0.32 & 0.05 & -0.13 & 0.41 & 0.41 & 0.01 & -0.55 & 0.001 \\
Emotional function & 0.29 & 0.07 & -0.05 & 0.74 & 0.24 & 0.15 & -0.63 & $<\mathbf{0 . 0 0 1}$ \\
Cognitive function & -0.05 & 0.75 & -0.05 & 0.76 & 0.22 & 0.18 & -0.5 & $<\mathbf{0 . 0 0 1}$ \\
Social function & 0.15 & 0.35 & 0.09 & 0.59 & 0.32 & 0.05 & -0.51 & 0.001 \\
Fatigue & -0.34 & 0.04 & 0.19 & 0.26 & -0.19 & 0.26 & 0.67 & $<\mathbf{0 . 0 0 1}$ \\
Nausea and vomiting & -0.21 & 0.21 & 0.08 & 0.64 & -0.29 & 0.08 & 0.14 & 0.01 \\
Pain & -0.19 & 0.24 & -0.07 & 0.66 & -0.21 & 0.20 & 0.52 & 0.001 \\
Dyspnea & -0.25 & 0.13 & 0.06 & 0.71 & -0.15 & 0.35 & 0.26 & 0.11 \\
Insomnia & -0.29 & 0.08 & 0.05 & 0.76 & -0.41 & 0.01 & 0.53 & 0.001 \\
Appetite loss & 0.008 & 0.96 & -0.08 & 0.63 & -0.31 & 0.06 & 0.39 & 0.01 \\
Constipation & 0.01 & 0.94 & -0.06 & 0.68 & -0.04 & 0.77 & 0.17 & 0.29 \\
Diarrhea & 0.01 & 0.93 & -0.09 & 0.58 & 0.01 & 0.92 & 0.25 & 0.12 \\
\hline & -0.17 & 0.29 & -0.18 & 0.28 & -0.17 & 0.30 & 0.37 & 0.02 \\
\hline
\end{tabular}

Note: *Pearson's correlation; **Significance level $(p<0.05)$
In terms of the functional scales, the mean results were higher than 60 . Among those, the most compromised domain was role playing and its lowest mean was 60.64. The highest mean refers to the cognitive function domain (77.28).

The symptom scale had low means, which represents a low level of symptoms. The predominant symptom was insomnia, whose mean was 37.08, followed by loss of appetite, fatigue, pain, constipation, dyspnea, diarrhea, and nausea and vomiting. In the scale of financial difficulties, the mean found was 31.47.

To verify whether sociodemographic and clinical category variables interfered with the domains investigated by the EORTCQLQ-C30, the Mann-Whitney's nonparametric test was applied. The results were considered statistically significant when $\mathrm{p} \leq$ 0.05, according to Table 2.

The comparison between the EORTC domains and sex did not show any significant difference, that is, men and women had a similar perception of their quality of life.

The statistically significant comparisons found were: marital status, social function scale, and the financial difficulty item; ostomy type and GHS; time of stoma with the social function scale and place of stoma with the cognitive and social function scales, and the symptom pain (Table 2).

Table 3 shows the correlation between the QoL domains and the quantitative variables. 
No statistically significant correlations were found for the QLQ-C-30 scales and the variable schooling. The variable age significantly influenced the QoL of ostomized patients in the domains GHS $(r=0.35, p=0.03)$, role playing $(r=0.32$, $p=0.05)$, and fatigue $(r=-0.34, p=0.04)$.

When correlating time of ostomy and the QoL domain scores, there was moderate, statistically significant correlation in role playing $(r=0.41)$, social function $(r=0.32)$, and in the symptom insomnia $(r=0.41)$.

Pearson's correlation between the QoL domains and selfesteem scores was significant, inverse, and had strong intensity in the GHS domains and in all the functional scales. The negative value of this correlation shows that the instruments are inversely measured, that is, the higher the EORTC score, the better the QoL and physical functioning. In contrast, the higher the RSS score, the lower the SE. Therefore, these results demonstrate that both instruments correlate inversely because it is expected that in order to have good QoL, it is necessary to have good SE.

In the symptom scales, there was significant correlation in most of the items. The weakest was in nausea and vomiting $(r=0.14)$ and the strongest in fatigue $(r=0.67)$. The correlations were positive, showing that high scores in the self-esteem scale increase the scores in these symptoms.

\section{DISCUSSION}

In terms of the sociodemographic characterization of the sample for this study, there was a predominance of male, elderly, retired ostomized patients with low schooling, which characterizes the public assisted by the Brazilian Unified Health System.

Self-esteem is evidenced in the answers given by individuals to different situations and life events ${ }^{(10)}$. It is also considered to be an important indicator of mental health because it interferes with affective, social, and psychological conditions. Having a stoma is something that may result in a distorted self image and decreased self-esteem, echoing in one's self perception and in seeing oneself as unattractive ${ }^{(10)}$. The sudden change in the body image creates confusion and a negative change in the way people perceive themselves ${ }^{(6,10)}$.

Regarding SE, the mean of the RSS scores was 18.88. These results enable researchers to conclude that, since the mean SE scores are far from the maximum score (40), this group's selfesteem is satisfactory, considering that the score of the scale varies from 10 to 40 and that the closer to ten, the better their self-esteem and the closer to 40, the worse their self-esteem. Different results have been found in another study ${ }^{(18)}$, whose goal was to assess self-esteem in patients with an intestinal stoma. The authors of that study concluded that the ostomized patients had their self-esteem compromised.

Among the analyzed variables (sex, marital status, age, schooling, family income, time of ostomy, type of ostomy, time of stoma), none showed a significant difference in relation to self-esteem $(p>0.05)$, that is, this finding suggests that this attribute is not necessarily associated with the abovementioned variables. Further research is necessary to clarify this issue, taking into account that relations among these variables impacted on SE in a similar study where male, married participants aged 60 years or older, with incomplete elementary school and with permanent ostomy had reduced self-esteem ${ }^{(18)}$.

In the past, the concern of healthcare professionals was the survival of patients diagnosed with cancer ${ }^{(19)}$. With a shift in focus, a current growing emphasis on HRQoL assessment among individuals who underwent anti-neoplasic treatment derives from factors such as advances in the detection and treatment of the disease, the need to measure the impact of the therapy, more optimistic social attitudes, increasing number of survivors, and concerns with patients' rights $^{(13)}$.

The opening of a stoma is considered one of the most important surgical accomplishments for people affected by colorectal cancer. It may alleviate symptoms, and restrict or hinder the evolution of the disease ${ }^{(20)}$. However, it implies changes in one's body image, loss of waste control, and need to use collector equipment ${ }^{(21-22)}$. Thus, ostomized patients develop physical, psychological, and social changes that may influence their HRQoL ${ }^{(13)}$.

Regarding quality of life, a study conducted in Malaysia ${ }^{(23)}$ that also used the QLQ-C30 with patients with colorectal cancer found better scores for the GHS, with a mean of 85.16.

In the functional scales, the physical, emotional, cognitive, and social functions had means that varied between 62.69 and 77.28. Role playing (60.64) was the most affected, as in another study ${ }^{(13)}$ where this domain had a 12.96 mean, showing that there is some level of hindrance to work or perform leisure activities, assessed by answers six and seven of the instrument.

Regarded as handicapped people, the ostomized patients live with biopsychosocial difficulties caused by the presence of a stoma, including barriers to social inclusion. A qualitative study ${ }^{(24)}$ described the changes occurred in the daily life of ostomized patients and identified restrictions in their leisure activities such as traveling, practicing sports, and going to clubs because of their insecurity about the bag adhesion. Another study ${ }^{(25)}$ used the questionnaire World Health Organization Quality of Life (WHOQOL)-bref to assess and compare the QoL between patients temporarily and permanently ostomized, finding in more than $50 \%$ of both groups dissatisfaction with the leisure opportunities and concerns regarding the exposure, rupture, and leaking of the collecting equipment.

The low scores in the symptom scale and single items showed that they are adequately controlled. In the scales of symptoms and single items, insomnia (37.08) was the most affected domain. Researchers suggest that additional research be made on sleeping problems in ostomized patients surviving CRC given the scarcity of studies about this issue.

The item financial difficulty had a 31.47 mean, a maximum score of 100 , and a 40.61 standard deviation. It is the second highest standard deviation value of all evaluated items, which shows that it was one of the items with greater difference in answers. The mean of this item points out to moderate financial difficulty level. The ostomy causes limitations in HRQoL, which lead to an exit from the job market; consequently, 
financial difficulties arise. Moreover, governmental aids and retirement bring significant wage reductions. A study conducted in Rio de Janeiro ${ }^{(26)}$ with ostomized patients showed that, among the 20 interviewees, 15 performed labor activities. Among the latter, 12 simultaneously received governmental help, alleging that this was not enough to support the family.

When relating QoL with the variable sex, no significant difference was found in the EORTC domains. Another study ${ }^{(27)}$ found high scores of pain, fatigue and dyspnea in women. Regarding marital status, it was possible to observe that ostomized patients without a spouse scored higher in the social domain, pointing out that the physical condition and treatment interfere less with the family life and social activities in comparison with participants who had a spouse. The opposite was expected, though. This result may be explained by the fact that the ostomized patients took into account the quality of the relationship rather than its mere existence. Still in terms of marital status, the physical condition and treatment caused greater financial difficulty in the group of patients with a spouse. An ostomy generates biopsychosocial changes, such as not returning to one's job, which explains this result.

The fact that the GHS is better perceived by colostomy carriers can be explained by the characteristic of consistency and volume of the effluent that are different between these and those who were submitted to the anastomosis from the ileum to the abdominal wall.

Regarding the time of stoma, patients who have been permanently ostomized had higher mean scores than those with a temporary ostomy; however, the social function was the only one to present a significant difference. A study ${ }^{(25)}$ that compared HRQoL between patients with permanent and temporary ostomy concluded that both suffer from the same distress, which equally affects quality of life. Having an intestinal ostomy for limited period does not exempt these people from suffering once they need to face the challenges caused by the impact of the ostomy in their lives.

As far as the location of the stoma is concerned, the cognitive and social functions were higher among patients who had been ostomized in their left side, whereas pain was higher among those with a right ostomy. It was difficult to compare these results with literature data on QoL because specific studies on the location of stomas were not found in Brazil or abroad.

Ostomies located in the lower right quadrant have effluents of a more liquid consistency that becomes thicker, with frequent discharges, more alkaline fluids and rich in enzymes. This may cause dermatitis and generate pain. It is possible to imply that social relations are more harmed in this group because of the need for frequent emptying and sanitation of the collecting equipment.

The variable age had a moderate and positive correlation with GHS and role playing; therefore, the older the age, the higher the scores in these domains. It was also moderate and inverse with fatigue, showing that fatigue increases as the age decreases. Different data were found in another study where age was one of the variables that did not have any correlation with any of the QoL domains ${ }^{(28)}$.

As expected, the ostomy time represents an important influence on the HRQoL factors. It has a correlation with role playing and social function, showing that the longer the ostomy time, the higher the scores in these domains. There is an opposite correlation with insomnia, that is, fewer symptoms with the longer ostomy time. These results are consistent with the literature that states that the adjustment to the ostomy requires time and the period for adjustment varies according to the individual ${ }^{(22,26)}$.

As time passes by and through the use of adjustment strategies found, the ostomized patients integrate changes more easily in all their multiple dimensions. Their acceptance may be enhanced by the integration with family members and friends and through a systematized intervention by healthcare professionals ${ }^{(22)}$.

The correlations between SE and the EORTC instrument were significant in all of the dimensions of the functional scales and GHS. This finding emphasizes the relation expected between SE and HRQoL, that is, the lower the self-esteem, the greater the harm to health-related quality of life. In the symptom scales, only dyspnea, constipation and diarrhea did not present any statistically significant correlations. The other dimensions of the symptoms and single items scales had positive correlations with the RSS. The higher the RSS score, the higher the scores in the symptom scales, which indicates limitations in HRQoL.

An ostomy may be a limiting factor for the HRQoL of CRC patients because physical and psychological difficulties coexist. Not only are they related to the illness, but also to the limiting aspects of the stoma ${ }^{(25)}$, such as those related to daily and labor capacity activities, that is, activities of the physical domain.

Attention to the emotional impact is essential in the care given to ostomized patients. It can be considered an important factor in these individuals' body image as it produces considerable psychological impact, changing their self-esteem and sometimes their social relations. An ostomization changes a person's image of oneself and one's body. It also brings up concerns about other people's perception of the patient's new condition ${ }^{(29)}$.

There was a correlation between SE and financial difficulty, showing that the lower the SE, the greater the financial difficulty, an important aspect that compromises HRQoL. An ostomy causes multiple limitations in quality of life, including a withdrawal from the job market. It is possible to conclude that the lack of financial resources may become very expressive, mainly when the disease affects the family member who is responsible for supporting the household ${ }^{(30)}$.

\section{Study limitations}

This study had limitations in terms of its cross-sectional cutoff and sample size. This fact is attributed to the previous cancer diagnosis where the survivors are those who managed to control their illness. Regarding the assessment of self-esteem and quality of life of ostomized patients by intestinal cancer, the literature is rather scarce. Researchers found the need for further research, especially with a quantitative approach.

\section{Contributions for the nursing field}

Knowledge on levels of self-esteem and health-related quality of life in ostomized patients due to colorectal cancer, as 
well as on the changes caused in their daily lives, offers support for planning the care provided by healthcare professionals, especially nurses. Provided with this knowledge, nurses can develop intervention strategies that minimize the upheavals resulting from ostomy, in addition to train professionals involved in health care.

\section{CONCLUSION}

The results of this study allowed for the analysis of selfesteem and health-related quality of life in ostomized patients due to CRC.

Their self-esteem was considered satisfactory. Individuals with a stoma located in the left abdominal quadrant presented higher SE.

In the relation between $\mathrm{HRQoL}$ and marital status, this study identified that ostomized patients without spouses had higher scores in the social function scale than those with spouses, in addition to greater financial difficulty. Individuals with colostomy had higher scores in the GHS. Patients with a permanent ostomy had higher scores in the social function.
Those whose ostomy was located in the left side had higher scores in the cognitive and social functions, whereas those whose ostomy was located on the right side had higher score in pain. Age was correlated to the GHS and role playing. The older the age, the higher these domains were. In contrast, the younger the age, the greater the fatigue.

As far as the ostomy time was concerned, in correlation to role playing and social function, the longer the ostomy time, the fewer the limitations in terms of work, leisure, and social interaction.

Regarding the EORTC domains and the self-esteem scores, this study found a strong inverse correlation in terms of GHS and all the functional scales. In other words, the higher the RSS scores, the lower the scores in the abovementioned domains with more harm to HRQoL.

\section{FUNDING}

Financial support (APQ - 02411-14) provided by the Minas Gerais State Agency for Research and Development (FAPEMIG).

\section{REFERENCES}

1. Francisco PMSB, Segri NJS, Malta DC. Desigualdades sociodemográfica nos fatores de risco e proteção para doenças crônicas não transmissíveis: inquérito telefônico em Campinas, São Paulo. Rev Epidemiol Serv Saúde[Internet]. 2015[cited 2016 Jan 10];24(1):7-18. Available from: http://www.scielo.br/pdf/ress/v24n1/2237-9622-ress-24-01-00007.pdf

2. Brasil. Ministério da Saúde. Instituto Nacional de Câncer. Estimativa 2016: incidência de câncer no Brasil Rio de Janeiro (RJ): INCA[Internet] 2016[cited 2016 Jan 10]. Available from: http://www.inca.gov.br/wcm/dncc/2015/dados-apresentados.pdf

3. CamposFG,Calijuri-HamraMC,ImperialeAR,KissDR,NahasSC,Cecconellol.Locallyadvancedcolorectalcancer:resultsofsurgicaltreatment andprognostic.RevArqGastroenterol[Internet].2011[cited2016]an10];48(4):270-75.Availablefrom:http://www.scielo.br/pdf/ag/v48n4/v48 n4a10.pdf

4. Manso MM, Kitamura NE, Souza JRM, Gonçalves JE, Matos LL, Mader AMAA, et al. Níveis séricos e imunoexpressão tecidual do marcador CA 19-9 no carcinoma colorretal e comprometimento linfonodal. Rev Arq Bras Ciênc Saúde[Internet]. 2011[cited 2016 Jan 10]; 36(1):29-34. Available from: http://files.bvs.br/upload/S/1983-2451/2011/v36n1/a1921.pdf

5. Huwe FG, Anton EM, Eisenhardt MF, Foletto E, Jackisch S, Severo B, et al. Avaliação das características clínicas e epidemiológicas e sobrevida global de pacientes portadores de câncer colorretal. Rev Epidemiol Control Infec[Internet]. 2013 [cited 2016 Jan 10];3(4):112-6. Available from: http://online.unisc.br/seer/index.php/epidemiologia/article/view/4117/3253

6. Mota MS, Gomes GC. Mudanças no processo de viver do paciente estomizado após a cirurgia. Rev Enferm UFPE[Internet]. 2013[cited 2014 Jul 10];7(esp):7074-81. Available from: http://www.revista.ufpe.br/revistaenfermagem/index.php/revista/article/ download/3435/8133

7. Nicolussi AC. Qualidade de vida de pacientes com câncer de cólon e reto: revisão integrativa da literatura[Internet]. [Dissertação]: Universidade de São Paulo, Escola de Enfermagem de Ribeirão Preto; 2008[cited 2016 Jan 10]. Available from: http://www.teses.usp.br/teses/ disponiveis/22/22132/tde-03092008-111111/pt-br.php

8. Torres CRD, Andrade EMLR, Ribeiro FMSS, Gonçalves Neta FCC, Luz MHBA. Qualidade de vida de pessoas estomizadas: revisão integrativa. Rev de Enferm UFPI[Internet]. 2015[cited 2016 Jan 10];4(1):117-22. Available from: http://www.ojs.ufpi.br/index.php/reufpi/ article/view/2242/pdf

9. Nascimento CMS, Trindade GLB, Luz MHBA, Santiago RF. Vivência do paciente estomizado: uma contribuição para a assistência de enfermagem. Texto Contexto Enferm[Internet]. 2011[cited 2015 Aug 10];20(3):357-64. Available from: http://www.scielo.br/pdf/tce/ v20n3/18.pdf

10. Schultheisz TSV, Aprile MR. Autoestima, conceitos correlatos e avaliação. Rev Equil Corp Saúde[Internet]. 2013 [cited 2014 Aug 16];5(1):36-48. Available from: http://www.pgsskroton.com.br/seer/index.php/reces/article/view/22/19

11. Erdogan B, Bauer TN, Truxillo DM, Mansfield LR. Whistle while you work: a review of life satisfaction literature. J Manag[Internet]. 2012[cited 2014 Mar 10];38(4):1038-83. Available from: http://jom.sagepub.com/content/early/2012/01/03/0149206311429379.full. pdf + html 
12. Sampaio FMC. A autoestima na pessoa portadora de ostomia de eliminação intestinal. Rev Port Enferm Saúde Mental[Internet]. 2010[cited 2014 Sep 10];3:31-7. Available from: http://comum.rcaap.pt/bitstream/123456789/6153/1/Revista4-Artigo4\%20\%281\%29.pdf

13. Kameo SY, Sawada NO. Qualidade de vida relacionada à saúde do paciente com estoma intestinal secundária ao câncer cólonretal. Rev Iberoamericana Educ Invest Enferm[Internet]. 2014[cited 2016 Jan 10];4(2):19-26. Available from: http://www.enfermeria21.com/revistas/aladefe/articulo/118.pdf

14. Freire MEM, Sawada NO, França ISX, Costa SFG, Oliveira CDB. Qualidade de vida relacionada à saúde de pacientes com câncer avançado: uma revisão integrativa. Rev Esc Enferm USP[Internet]. 2014[cited 2015 Jun 10];48(2):357-67. Available from: http://www.scielo.br/ pdf/reeusp/v48n2/pt_0080-6234-reeusp-48-02-357.pdf

15. Gimenes GF. Usos e significados da qualidade de vida nosdiscursos contemporâneos de saúde. Rev Trab Educ Saúde [Internet]. 2013[cited 2015 Jan 10];11(2):291-318. Available from: http://www.scielo.br/pdf/tes/v11n2/a03v11n2.pdf

16. Dini GM, Quaresma MR, Ferreira LM. Adaptação cultural e validação da versão brasileira da Escala de Autoestima de Rosenberg. Rev Soc Bras Cir Plást[Internet]. 2004[cited 2015 Jun 10];19(1):41-52. Available from: http://www.rbcp.org.br/imagebank/pdf/1901-04pt.pdf

17. Brabo EP, Paschoal MEM, Biasoli I, Nogueira FE, Gomes MCB, Gomes IP, et al. Brazilian version of the QLQ-LC13 lung cancer module of the European Organization for Research and Treatment of cancer: preliminary reliability and validity report. Qual Life Res[Internet]. 2006[cited 2015 Jun 10];15(9):1519-24. Available from: http://download.springer.com/static/pdf

18. Salomé GM, Almeida SA, Silveira MM. Quality of life and self-esteem of patients with intestinal stoma. J Coloproctol [Internet]. 2014[cited 2015 Oct 10];34(4):231-9. Available from: http://www.scielo.br/pdf/jcol/v34n4/2237-9363-jcol-34-04-0231.pdf

19. Chaves PL, Gorini MIPC. Qualidade de vida do paciente com câncer colorretal em quimioterapia ambulatorial. Rev Gaúcha Enferm[Internet]. 2011 [cited 2016 Oct 10];32(4):767-73. Available from: http://www.scielo.br/pdf/rgenf/v32n4/v32n4a18.pdf

20. Taylor C, Morgan L. Quality of life following reversal of temporary stoma after rectal cancer treatment. Rev Europ J Oncol Nurs[lnternet]. 2011[cited 2014 Jun 10];15(1):59-66. Available from: http://www.sciencedirect.com/science/article/pii/S1462388910000943

21. Franco VQ. et al. Inclusão laboral da pessoa estomizada sob a ótica do capitalismo neoliberal. Rev Enferm Prof[Internet]. 2014 [cited 2015 Jun 10];1(2):291-303. Available from: http://www.seer.unirio.br/index.php/enfermagemprofissional/article/view/3699/pdf_1410

22. Sousa CF, Santos C, Graça LCC. Construção e validação de uma escala de adaptação a ostomia de eliminação. Rev Enf Ref[Internet]. 2015[cited 2015 Jun 10];4(4):21-30. Available from: http://www.redalyc.org/articulo.oa?id=388239974002

23. Wan Puteh SE, Saad NM, Aljunidet SM, Manaf MRA, Sulong S, Sagap I, et al. Quality of life in Malaysian colorectal cancer patients. Rev Asia Pacific Psych[Internet]. 2013[cited 2015 Jun 10]; 5(suppl.1):110-7. Available from: http://onlinelibrary.wiley.com/ doi/10.1111/appy.12055/epdf

24. Coelho AR, Santos FS, Dal Poggetto MT. A estomia mudando a vida: enfrentar para viver. REME Rev Min Enferm[Internet]. 2013[cited 2015 Sep 10];17(2):22-31. Available from: http://www.reme.org.br/artigo/detalhes/649

25. Fortes RC, Monteiro TMRC, Kimura CA. Quality of life from oncological patients with definitive and temporary colostomy. Journal of Coloproctology [Internet]. 2012[cited 2015 Mar 16];32(3):253-9. Available from: http://www.scielo.br/pdf/jcol/v32n3/a08v32n3

26. Mauricio VC, Souza NVDO, Lisboa MTL. O sentido do trabalho para o ser estomizado. Texto Contexto Enferm[Internet]. 2014 [cited 2015 Sep 10];23(3):656-64. Available from: http://www.scielo.br/pdf/tce/v23n3/pt_0104-0707-tce-23-03-00656.pdf

27. Natrah MS, Ezat S, Syed MA, Rizal AM, Saperi S. et al. Quality of life in Malaysian colorectal cancer patients: a preliminary result. Asian Pac J Cancer Prev[Internet]. 2012[cited 2015 Sep 10];13(3):957-62. Available from: http://journal.waocp.org/article_26273_d5b381c01cb6beec28db76d65715fe1d.pdf

28. Pereira APS, Cesarino CB, Martins MRI, Pinto MH, Netinho JG. Associação dos fatores sociodemográficos e clínicos à qualidade de vida dos estomizados. Rev Latino-Am Enfermagem[Internet]. 2012[cited 2015 Sep 10];20(1):93-100. Available from: http://www.scielo.br/pdf/ rlae/v20n1/pt_13.pdf

29. Souza ECA, Figueiredo GLA, Lenza NFB, Sonobe H. Consequências da estomia intestinal para os estomizados e seus familiares. Rev Enferm UFPE[Internet]. 2010[cited 2015 Sep 10];4(esp):1081-6. Available from: http://www.revista.ufpe.br/revistaenfermagem/index.php/revista/article/viewFile/942/pdf_102

30. Ferreira NML, Dupas G, Costa DB, Sanchez KOL. Câncer e família: compreendendo os significados simbólicos. Rev Ciênc Cuid Saúde[Internet]. 2010[cited 2015 Sep 10];9(2):269-77. Available from: http://periodicos.uem.br/ojs/index.php/CiencCuidSaude/ article/view/8749/6076 